\title{
Deviations of the CtP Printing Plates Quality Caused by Chemical Processing
}

\author{
PoljaceK Mahovic, S.; Agic, D. \& Gojo, M.
}

Abstract: The aim of this research was to make a comparison between the ageing process of the developing solution and the adsorption of the fountain solution on the $C t P$ printing plates. Different adsorption is mostly caused by variations in chemical processing conditions. According to that, physical and chemical characteristics of the fountain and developing solutions were measured within different processing conditions. The investigation has showed that during the ageing of the developer solution certain physical - chemical changes have appeared. These changes can considerably influence the application of the fountain solution on the printing plate and can result with incorrect water-ink balance during the printing process.

Key words: CtP printing plates, quality control, chemical processing
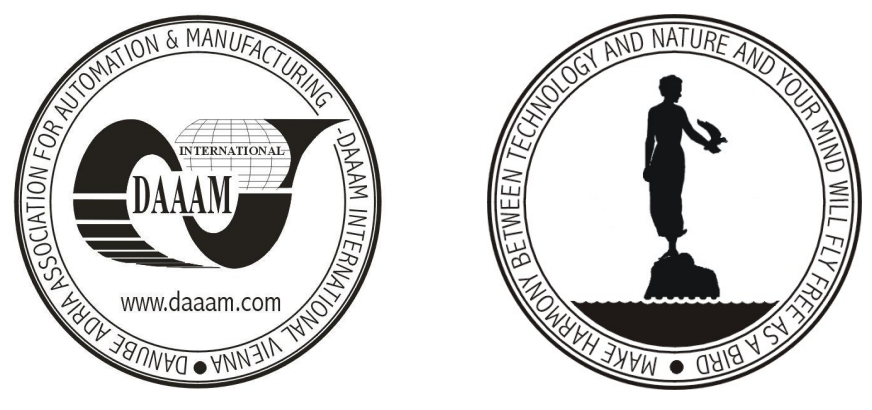

Authors' data: Ph.D. Ass. Poljacek Mahovic, S[anja]; Ph.D. Ass. Prof. Agic, $\mathrm{D}$ [arko], Ph.D. Prof. Gojo, M[iroslav], Faculty of Graphic Arts, University of Zagreb, Getaldiceva 2, 10000 Zagreb, Croatia, smahovic@grf.hr, agic@grf.hr , mgojo@grf.hr

This Publication has to be referred as: Poljacek Mahovic, S.; Agic, D. \& Gojo, M. (2007). Deviations of the Ctp Printing Plates Quality caused by Chemical Processing, Chapter 03 in DAAAM International Scientific Book 2007, B. Katalinic (Ed.), Published by DAAAM International, ISBN 3-901509-60-7, ISSN 1726-9687, Vienna, Austria

DOI: $10.2507 /$ daaam.scibook.2007.03 